\section{Cerebrovascular Diseases}

\title{
Johann Jacob Wepfer Award 2005 of the ESC to Dr. Jean-Claude Baron
}

On behalf of the programme and scientific committees, we are happy to introduce the first ESC award for excellence in clinical and basic stroke science, which is given in conjunction with the first J.J. Wepfer lecture after a careful selection by the conference committee.

The first modern descriptions of the encephalic arteries as well as the first modern studies of the consequences of their blockage for the brain do not appear before the 17 th century. Thomas Willis is often considered as the father of modern neurovascular anatomy. However, he had a great predecessor, only a few years before he published his main treatise; this predecessor was only 1 year older, and his name was Johann Jacob Wepfer, a Swiss physician from Schaffhausen, who was affiliated to a convent, where he was able to follow his patients from disease to autopsy. He provided the best descriptions of the vascular anatomy of the brain in the 1650s, which were then summarized in his opus magnum 'Historiae apoplecticum'. Six years before Willis, he made a perfect description of the polygon of arteries which sits at the bottom of the brain. He also reported the way the carotids penetrate into the skull, forming the segment now called the carotid siphon. His insight into clinical correlations was also in advance over his time, since he reported on the apoplectic manifestations secondary to carotid artery blockage and bleeding into the brain and he was the first to emphasize the association of speech disorders with right hemiplegia, indeed 150 years before Bouillaud.

It is thus particularly appropriate that the first award of the J.J. Wepfer lecture is given to a great pioneer of the pathophysiology of vascular brain damage around the millennium. Jean-Claude Baron was born in 1949 and obtained his medical degree from Paris University in 1973, followed by a thesis in 1976. His expertise in PET started during a fellowship at MGH with R. Ackerman in 1976-1977 and subsequent training in biophysics and nuclear medicine in France. He became a research associ- ate at the Atomic Energy Commission at the Frederic Joliot Center in Orsay, before being appointed in 1986 and for the next 15 years Director of Research in neurosciences at the INSERM, first in Paris, then in Caen. In Caen, he became the scientific director of the Cyceron PET center. In between he had also found the time to obtain a sophisticated clinical training in neurology at $\mathrm{La}$ Salpétrière, where he was appointed senior registrar from 1982 to 1986 . The year 2000 represents a major point in Dr. Baron's career, as he was elected professor and chair of stroke medicine in the Department of Neurology at the University of Cambridge, UK, and honorary neurology consultant at Addenbrooke's hospital, and subsequently chairman of the Wolfson Brain Imaging Centre/Stroke Research Strategy and PET Users Groups, fellow of the Royal College of Physicians and of the Academy of Medical Sciences in the UK. Dr. Baron is involved in numerous scientific boards in Europe and beyond, and has published over 200 peer-reviewed papers in major scientific journals, mostly on the study of the ischemic process during acute stroke. Among his many scientific appointments, one may mention that he was president of the Société de Circulation et Métabolisme du Cerveau for the 1989-1991 period. Well, quite a striking and productive academic career, which perhaps was not obvious, initially, to the 24-year-old physician who made his debuts in medicine as a GP at Zomba General Hospital in Malawi. Dr. Baron is one of the most prominent European stroke experts, who has been successful in combining research and clinical science, on both sides of the Channel. He has been very supportive to the development of a European Stroke Community, and was already member of the scientific committee of the 1st ESC in 1990. We are glad and honoured to have Dr. Baron among us today, and to give him the podium for the J.J. Wepfer lecture.

\section{J. Bogousslavsky, M. Hennerici}

\begin{tabular}{ll}
\hline KARGER & ( ) 2005 S. Karger AG, Basel \\
1015-9770/05/0203-0152\$22.00/0 \\
$\begin{array}{l}\text { Fax +4161306 1234 } \\
\text { E-Mail karger@karger.ch } \\
\text { www.karger.com }\end{array}$ & $\begin{array}{l}\text { Accessible online at: } \\
\text { www.karger.com/ced }\end{array}$
\end{tabular}




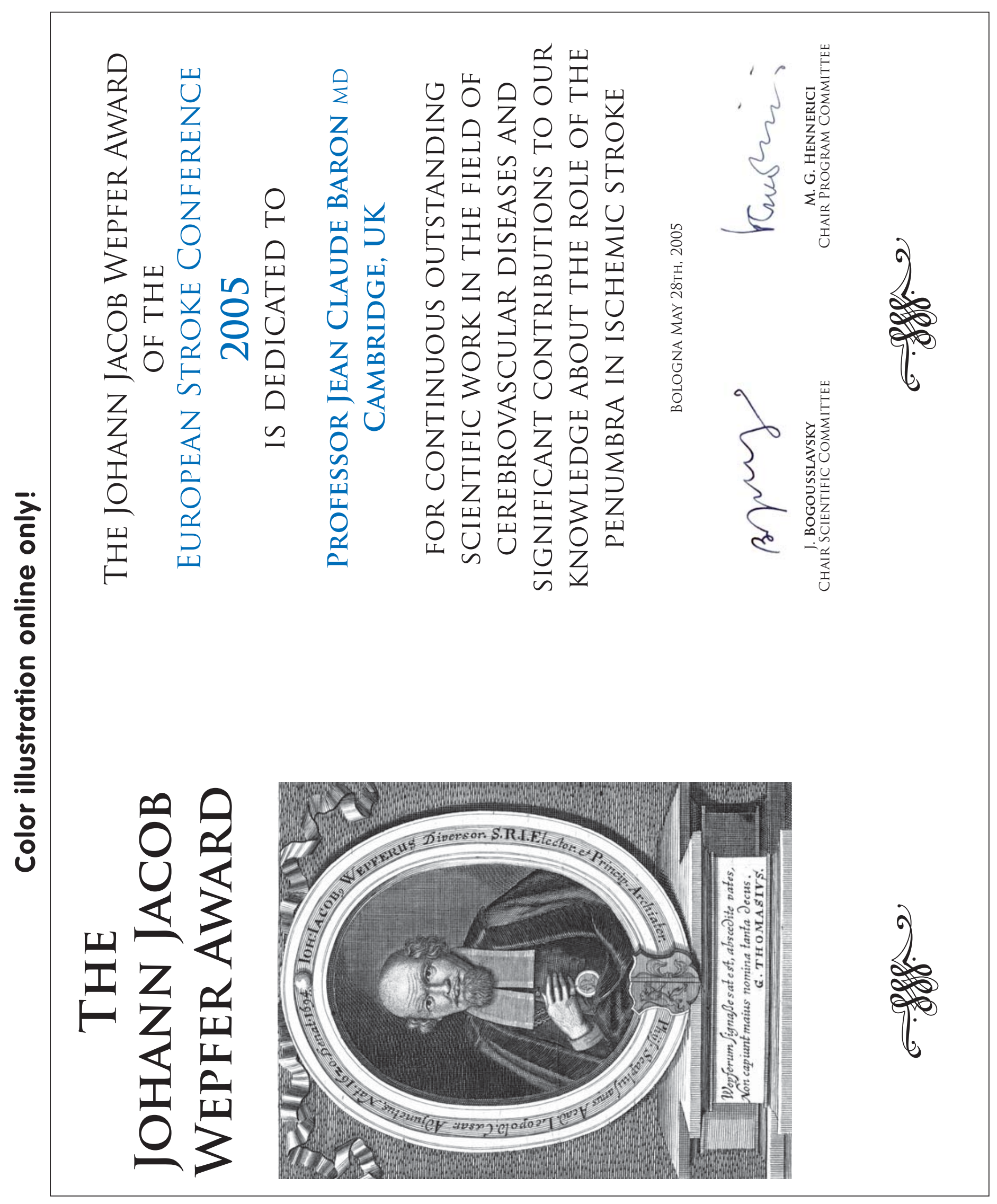

